УДК 378:373.2.011.3-051:316.47:376-056.36

ЛАРИСА ЗДАНЕВИЧ, доктор педагогічних наук, професор, завідувач кафедри дошкільної педагогіки, психології та фахових методик,

Хмельницька гуманітарно-педагогічна академія, Украӥна ORCID ID 0000-0001-8387-2143

larisazdan@ukr.net

ТЕТЯНА ЦЕГЕЛЬНИК, викладач кафедри дошкільної педагогіки, психології та фахових методик, Хмельницька гуманітарнопедагогічна академія, Украӥна ORCID ID 0000-0001-7643-0208 sveettana@ukr.net

\title{
ПІДГОТОВКА МАЙБУТНІХ ВИХОВАТЕЛІВ ДО ФОРМУВАННЯ ПОЗИТИВНИХ МІЖОСОБИСТІСНИХ ВЗАЕМИН ТА НАВИЧОК СПІЛКУВАННЯ ДІТЕЙ ДОШКІЛЬНОГО ВІКУ 3 ОСОБЛИВИМИ ОСВІТНІМИ ПОТРЕБАМИ
}

LARYSA ZDANEVYCH, doctor of pedagogical sciences, professor, head of the department of pre-school pedagogy, psychology and professional methods, Khmelnytskyi Humanitarian-

Pedagogical Academy, Ukraine

TETIANA TSEHELNYK, teacher of the department of pre-school pedagogy, psychology and professional methods, Khmelnytskyi Humanitarian-Pedagogical Academy, Ukraine

\section{PREPARING OF FUTURE EDUCATORS TO THE FORMATION OF A POSITIVE INTERPERSONAL RELATIONS AND SKILLS FOR COMMUNICATION BY PRESCHOOLERS WITH SPECIAL EDUCATIONAL NEEDS}

\begin{abstract}
У статті представлено теоретичне обгрунтування проблеми підготовки майбутніх вихователів до формування позитивних міжособистісних взаємин та навичок спілкування дітей дошкільного вікуз особливими освітніми потребами. Авторами представлено власне розуміння готовності до професійної діяльності в умовах інклюзії, їі основні компоненти та визначено складові професійної компетентності майбутніх вихователів закладів дошкільної освіти для роботи в інклюзивній освіті. Зазначено, що завдяки цьому вибудовуються актуальні компетенції педагогічної роботи в умовах інклюзії щодо формування позитивних міжособистісних взаємин та навичок спілкування дітей з особливими освітніми потребами.

Ключові слова: майбугні вихователі, інклюзивна освіта, міжособистісні взаємини, навички спілкуван-
\end{abstract}

(C) Л. Зданевич, Т. Цегельник ня, діти 3 особливими освітніми потребами, фахова підготовка.

Summary. The article has presented the theoretical substantiation of the problem of preparing future educators to the formation of positive interpersonal relationships and communication skills of preschoolers with special educational needs. The authors have presented their own understanding of readiness to professional activity in the conditions of inclusion, its main components and defined the components of professional competence of future educators to work in inclusive education. It has been stated that due to this the actual competences of pedagogical activity in the conditions of inclusion have been formed in order to form positive interpersonal relations and communication skills of children with special educational needs.

Key words: future educators, inclusive education, interpersonal relationships, communication skills, children with special educational needs, professional preparing.

Мета: теоретично обгрунтувати проблемупідготовки майбутніх вихователів до формування позитивних міжособистісних взаємин та навичок спілкування дітей дошкільного віку $з$ особливими освітніми потребами.

Постановка проблеми в загальному вигляді. Упровадження інклюзивного навчання у вітчизняну систему освіти, зокрема дошкільну, є вимогою сучасного демократичного суспільства, що означає забезпечити право на освіту всім своїм громадянам, у тому числі дітям з особливими освітніми потребами. Необхідність у спілкуванні в дітей дошкільного віку-одна 3 основних соціальних потреб. 3 віком це розширюється і поглиблюється як за формою, так і змістом. При цьому в дошкільному періоді особливо гостро проявляється потреба у спілкуванні з однолітками в дітей, котрі опинилися у важких життєвих ситуаціях, 
у виборі конструктивних способів вирішення проблемних ситуацій у процесі спілкування, у позитивних взаєминах з однолітками в інклюзивних групах.

Спілкування з однолітками займає провідне місце в розвитку інтелектуальних, мовленнєвих, емоційних і моральних задатків у дошкільному віці. Соціальний, особистісний і фізичний розвиток дитини-дошкільника безпосередньо пов'язаний з тим, як складаються ії̈ стосунки з однолітками. Але, на жаль, у процесі спілкування дітей в інклюзивних групах відзначається ряд негативних проявів: незадоволеність сформованими взаєминами з однолітками, почуття неоціненності і відстороненості, агресивність, тривожність, закріплення негативних емоцій тощо. Ураховуючи зазначене вище, майбутній вихователь повинен оволодіти відповідними фаховими компетентностями, які забезпечать йому ефективну діяльність в умовах інклюзивного середовища, здатність вирішувати проблеми, що виникають між дітьми 3 особливими освітніми потребами, та допомогу батькам у питаннях соціалізації, освіти і розвиткуїхніх дітей.

Аналіз досліджень і публікацій свідчить про значний інтерес науковців і практиків до питань інклюзивної освіти (В. Бондар, О. Будник, I. Демченко, І. Дубковецька, В. Засенко, А. Колупаєва, С. Литовченко, Ю. Найда, С. Сидорів, В. Синьов, Є. Синьова, В. Тищенко, С. Федоренко, Н. Шматко та ін.), проблем міжособистих стосунків і психологічного клімату в інклюзивному середовищі (Т. Кожекіна, В. Циренов та ін.). Фахова підготовка майбутніх вихователів закладів дошкільної освіти є предметом вивчення Л. Артемової, Г. Бєлєнької, А. Богуш, Н. Гавриш, І. Дичківської, Л. Зданевич, К. Крутій, Т. Поніманської та інших. Слід зазначити, що в рамках нашого дослідження актуальними вважаємо напрацювання вітчизняних та зарубіжних науковців з питань дитячої психології (Б. Волков, Т. Дуткевич, Г. Люблінська, Т. Марцинковська, Р. Павелків, О. Шаграєва та ін.) і лінгводидактики (А. Богуш, Н. Гавриш, О. Саприкіна, Ф. Сохін та ін.).

Виклад основного матеріалу дослідження. Проблема формування позитивних міжособистісних взаємин та навичок спілкування є однією з провідних у царині дошкільної освіти, оскільки обидва зазначені аспекти забезпечують вільне "входження" дитини- дошкільника в навколишній світ, соціалізацію і життєдіяльність у ньому. Про це наголошується у Базовому компоненті дошкільної освіти, де зміст освітньої лінії "Дитина в соціумі" передбачає формування у дітей навичок соціально визнаної поведінки, уміння орієнтуватись у світі людських взаємин, готовності співпереживати та співчувати іншим. Завдяки спілкуванню 3 дорослими як носіями суспільно-історичного досвіду людства в дитини з'являються інтерес та вміння розуміти інших, долучатися до спільної діяльності з однолітками та дорослими, об'єднувати 3 ними свої зусилля для досягнення спільного результату, оцінювати власні можливості, поважати бажання та інтереси оточуючих. Взаємодія з іншими людьми $є$ своєрідним видом входження дитини в людський соціум, що вимагає уміння узгоджувати свої інтереси, бажання, дії з членами суспільства.

Освітня лінія "Мовлення дитини" передбачає засвоєння нею культури мовлення та спілкування, елементарних правил користування мовою у різних життєвих ситуаціях. Оволодіння мовою як засобом пізнання і способом специфічно людського спілкування вважаємо найвагомішим досягненням дошкільного дитинства. Мова виступає "каналом зв'язку" для одержання інформації з немовних сфер буття, засобом пізнання світу від конкретно-чуттєвого до понятійно-абстрактного. Мовленнєве виховання забезпечує духовно-емоційний розвиток дитини через органічний зв'язок 3 національним вихованням. Мовленнєва діяльність дітей дошкільного віку складається з різних видів говоріння та слухання, під час якої формуються мовленнєві вміння і навички. Вивчення української мови в закладах дошкільної освіти національних спільнот передбачає залучення дітей інших національностей, які є громадянами України, до оволодіння українською мовою як державною на рівні вільного спілкування з іншими дітьми і дорослими, виховання інтересу та позитивного ставлення до української мови (Богуш, 2012, с. 6-7).

Зазначимо, що соціальне виховання має спрямовуватися на розв'язання проблем, які виникають у процесі входження дитини в нові умови життя, налагодження спілкування та спільної з іншими діяльності. Відповідно завдання вихователя - не просто допомогти вихованцеві "вписатися" в реальні соціальні умови, а й гармон- ійно поєднати їх з індивідуальними бажаннями, прийнятними для людей, котрі оточують (Кононко, Плохій \& Гончаренко, 2009, с. 106). Основою соціалізації особистості є соціальний досвід, засвоюючи який дитина здійснює власний саморозвиток та самореалізацію, стає соціально компетентною. Соціальна компетентність - це складна полікомпонентна властивість особистості, іiї інтегральна якість, яка складається з комплексу емоційних, мотиваційних, характерологічних особливостей і виявляється в соціальній активності та гуманістичній спрямованості (Богуш, Варяниия, Гавриш, Курінна \& Печенко, 2006, c. 201).

Що стосується дітей $з$ особливими освітніми потребами (діти, чиї освітні потреби виходять за межі загальноприйнятої норми), то аналіз наукових досліджень показав, що поведінка і спілкування їх у суспільстві визначається як біогенними, так і соціогенними факторами. При цьому труднощі, які виникають у дітей, визнаються такими "від природи", а соціальні умови і можливості часто недооцінюються. Серйозні проблеми у процесі соціалізації та спілкування в цих дошкільників пов'язані, на нашу думку, з педагогічною некомпетентністю окремих вихователів та батьків, невідповідним вихованням у ранньому віці, ізоляцією, що призводить до соціальної безпорадності, та, нажаль, iз частим негативним ставленням оточуючих до них як до "неповноцінних". Саме тому формування в дітей дошкільного віку з особливими освітніми потребами позитивних міжособистісних взаємин та розвиток спілкування мають свою специфіку, оволодіння якою $€$ першочерговим завданням майбутніх вихователів закладів дошкільної освіти (ЗДО), які здійснюватимуть свою професійну діяльність згідно з вимогами інклюзивної освіти.

Інклюзія $є$ процесом збільшення участі кожної дитини окремо в соціальному житті ЗДО, а також зниження рівня ізоляції дітей в усіх навчально-виховних процесах. Інклюзія сприяє реструктуризації культури ЗДО, його правил і внутрішніх норм, практик для повного прийняття усього різноманіття дітей з їх особистими особливостями і потребами. Вона безпосередньо торкається усіх дітей, а не тільки особливо уразливих категорій, таких як діти з обмеженими можливостями; орієнтована на вдосконалення ЗДО не лише для дітей, але 
і працівників. Кожна дитина має право відвідувати ЗДО поруч зі своїм домом. Різноманіття і несхожість дітей один на одного характеризуються не проблемою, а найважливішим ресурсом, який можна використати в освітньомупроцесі. Інклюзія - це наявність тісних, грунтованих на дружбі взаємин між ЗДО та суспільством. Таким чином, інклюзія - це процес розвитку гранично доступної освіти для кожного в освітніх установах, формування навчально-виховних процесів 3 постановкою адекватних цілей усіх дітей, процес ліквідації різних бар'єрів для найбільшої підтримки кожного та максимального розкриття їх потенціалу (Патрикєєва, 2011, с. 45). Інклюзія, за визначенням О. Нижник, - створення у групі умов, які диктуються змістом і методами пізнавальної діяльності для повної включеності кожного; здатність колективу або співтовариства брати на себе відповідальність i сприяти рішенню проблем, що виникають з особливостей початкових даних дітей (Нижник, 2004, с. 91).

Вихователь $€$ найважливішою ланкою в організації інклюзивного навчання. Для роботи 3 дітьми, котрі мають особливі освітні потреби, потрібно вміти здійснювати діагностику їхніх можливостей і потреб, давати їм кваліфіковану оцінкута розробляти на цій основі індивідуальні навчальні програми, відмовляючись від колективних методів. Для цього, як зауважує I. Кузава, вихователь має володіти глибокими знаннями з усіх дисциплін, методики викладання, а також методики роботи 3 дітьми з особливостями психофізичного розвитку. Погоджуємося 3 дослідницею, що професійна компетентність вихователів закладу дошкільної освіти передбачає формування їхньої активної життєвої позиції, адаптацію, готовність до безперервної освіти тощо. В інклюзивному підході закладені можливості змінювати освітню ситуацію, створювати нові форми і способи організації навчально-виховного процесу з урахуванням індивідуальних відмінностей дітей. Зокрема, вихователь повинен володіти особливим набором професійних якостей, які дозволять йому реалізувати інклюзивну практику. Тобто професійно компетентний фахівець має не лише розуміти сутність та специфіку ситуації чи проблеми, але й уміти вирішувати ії практично, бути вмотивованим щодо вирішення, а також аналізувати як свою діяльність, так і ії наслідки (Кузава \&

\section{Ярмолюк, 2016, с. 78).}

Отже, для організації інклюзивної освіти дошкільників слід добре знати психолого-педагогічні, фізіологічні особливості дітей з особливими потребами. Оскільки діти з різними порушеннями повинні отримати можливість вільного вибору освітньої установи, кожен педагог має бути підготовленим до професійної діяльності в умовах інклюзії. Інклюзивна освіта вимагає від нього іншого рівня підготовки, високого професіоналізму, творчості, не тільки володіння знаннями у сфері спеціальної педагогіки, але і здатністю застосовувати їх у нестандартних ситуаціях. Усе зазначене міститься в понятті компетентність, яка передбачає цілісний досвід вирішення життєвих і професійних проблем. У цьому ракурсі важливою умовою досягнення професіоналізму $\epsilon$ формування "інклюзивної" готовності, що забезпечує можливість вихователю ефективно здійснювати свою професійну діяльність в умовах спільного навчання дітей з особливими освітніми потребами та їх однолітків, котрі нормально розвиваються (Кас'яненко, 2018, с. 39).

У нашому дослідженні готовність до професійної діяльності в умовах інклюзії розуміємо як стійку характеристику особистості, синтез ії властивостей і психічний стан, що перетворюється у стійку якість особистості у процесі діяльності. Як процес така готовність має свої закономірності, особливості, структурні елементи, критерії та рівні сформованості. Основними компонентами готовності до професійної діяльності в умовах інклюзії виступають теоретичні та методичні знання, професійні практичні вміння, позитивне ставлення до даного виду діяльності, яке, опираючись на принцип про провідну роль мотивів в активізації діяльності особистості, виділяється як основне.

Відомо, що про професійну компетентність можна говорити на стадії професійної підготовки фахівця. В освітньому процесі в майбутніх вихователів формуються і розвиваються професійні компетенції, що визначають готовність до діяльності. У зв'язку 3 цим компетентність стає інструментом професійної діяльності, що забезпечує їі успішність, оскільки випускник закладу вищої освіти повинен буги адаптованим до змін, володіти сформованими здібностями, постійно займатись самоосвітою і практичною діяльністю.
Однією із складових професійної компетентності майбутнього вихователя $є$ психологічна готовність до роботи в умовах інклюзії, особливостями якої зумовлюється іiї якість, стійкість та успішність. Вивчаючи структуру психологічної готовності до професійної діяльності та зміст компонентів, iї можна формувати і розвивати як особистісну якість у цілому, так і окремі її складові. Тому професійна підготовка фахівців виступає невід'ємним процесом формування психологічної готовності до професійної діяльності в умовах інклюзії як найважливішого, складного, стійкого особистісного утворення, що має вирішальне значення для успішного виконання функціональних обов'язків як у звичайних, так і складних, екстремальних умовах діяльності. Відповідно в нашому дослідженні складниками психологічної готовності визначаємо: емоційне прийняття дітей з різними типами порушень у розвитку; залучення дітей з вадами в діяльність під час занять; задоволеність власною педагогічною діяльністю.

Погоджуємося 3 I. Кузавою, що структуру інклюзивної освіти складають такі компоненти професійної готовності вихователів: 1) особистіснозмістовий (прийняття педагогом ідеї інклюзії, мотивація); 2) когнітивний (включає комплекс спеціальних професійно-педагогічних знань, умінь і навичок щодо здійснення інклюзивної освіти дошкільників, які потребують корекції психофізичного розвитку); 3) технологічний (практичні вміння вихователів у застосуванні технологій інклюзивної освіти дошкільників, зокрема, створення інклюзивного середовища); 4) креативний (творча активність і особистісні якості вихователя при створенні нових матеріальнодуховних цінностей та розвитку творчого потенціалу вихованців, які потребують корекції психофізичного розвитку); 5) оцінно-результативний (аналіз способів і прийомів, необхідних для впровадження інклюзивної освіти) $(K y$ зава \& Ярмолюк, 2016, с. 79).

Виходячи з окресленого, до складових професійної компетентності майбутніх вихователів закладів дошкільної освіти для роботи в інклюзивній освіті відносимо:

- блок знань 3 педагогічних дисциплін та фахових методик дошкільної освіти;

- мінімальний або поглиблений блок знань про відхилення у розвитку та основи корекційної роботи, адже 
педагог повинен бути зорієнтований в основних аспектах нозології відхилень та ознайомлений 3 можливостями корекційної педагогіки;

• володіння гнучкими формами та методами інтерактивного навчання;

- уміння мотивувати самостійну пізнавальнудіяльність;

- уміння працювати в команді, взаємодіяти 3 фахівцями для вибудови психологічного супроводу навчання дітей з особливими освітніми потребами;

- володіння сучасними технологіями виховної роботи з метою створення особливої атмосфери і формування позитивних міжособистісних взаємин.

Нам імпонує думка О. Будник про те, що важливими завданнями підготовки майбутніх фахівців є: сформувати у студентів цілісне уявлення про сутність і головні завдання інклюзивної освіти; розвинути навички здійснення індивідуального підходу в навчанні і вихованні дітей з особливими потребами; забезпечити опанування методами міжособистісної взаємодії з батьками дітей з особливими потребами, сформувати навички диференційованого викладання та оцінювання в умовах інклюзивного навчання (Будник, 2015).

Також вважаємо, що одним з важливих блоків знань у підготовці майбутніх фахівців $є$ знання про ті чи інші відхилення у розвитку та основи корекційної роботи. Через опанування даного блоку знань вибудовуються актуальні компетенції педагогічної діяльності в умовах інклюзії щодо формування позитивних міжособистісних взаємин та навичок спілкування дітей з особливими освітніми потребами. Власна професійна діяльність дає можливість стверджувати, що особливу роль в означеномуздатні зіграти спеціальні тренінги, спрямовані на підвищення психологічних знань і педагогічних компетенцій майбугніх вихователів. Завданням таких тренінгів $є$ умотивоване підвищення педагогічної компетентності, а їхній зміст направлений на: сприйняття педагогами філософії інклюзії; удосконалення умінь спостерігати за дитиною, фіксуючи зміни у ії поведінці і навчанні; умотивованого прагнення до ліквідації прогалин у професійних знаннях; установку на тісну співпрацю $з$ батьками дитини щодо формування позитивних міжособистісних взаємин та навичок спілкування.
Висновки та перспективи подальших досліджень. Педагогічний процес в умовах інклюзивної освіти вибудовується 3 включенням в його структуру цілей виховання і навчання, що забезпечують реалізацію права на освіту дітей дошкільного віку 3 особливими освітніми потребами. Формування позитивних міжособистісних взаємин та навичок спілкування дітей дошкільного вікуз особливими освітніми потребами є надзвичайно складним процесом, ураховуючи специфіку вихованців, а отже, потребує високого рівня фаховості майбутніх вихователів ЗДО. Відповідно, компетентнісний підхід, який акцентує увагу на результативності освіти, у нашому дослідженні полягає не в певній сумі отриманих майбутніми вихователями знань, а уздатності діяти в різних проблемних ситуаціях, зумовлених специфікою інклюзивної освіти.

Подальші перспективи в цьому напрямі вбачаємо в дослідженні інклюзивної компетентності як складової фахової компетентності майбутнього вихователя ЗДО.

\section{СПИСОКЛІТЕРАТУРИ}

Богуш, А. М. (2012). Базовий компонент дошкільної освіти. Київ.

Будник, О. Б. (2015). Інклюзивна освіта. Івано-Франківськ : Видавець Кушнір Г. М.

Богуш, А. М., Варяниця, Л. О., Гавриш, Н. В., Курінна, С. М., Печенко, I. П. (2006). Діти і соціум: особливості соціалізації дітей дошкільного та молодшого шкільного віку. Луганськ : Альма-матер.

Патрикєєва, О. О. та ін. (2011). Індекс інклюзії: загальноосвітній навчальний заклад. Київ : Плеяди.

Кас'яненко, О. М. (2018). Формування готовності майбутніх вихователів до роботи з дітьми дошкільного віку в умовах інклюзії. (Дис. канд. пед. наук). Тернопіль.

Кузава, І., Ярмолюк, М. (2016). Формування професійної готовності майбугніх вихователів до впровадження інклюзивної освіти. Науковий вісник Східноєвропейського національного університету імені Лесі $У_{\kappa-}$ раӥнки. Педагогічні науки, 2 (2), 7581. Взято з http://nbuv.gov.ua/UJRN/ Nvvnup_2016_2\%282\%29_14

Кононко, О. Л., Плохій, 3. П., Гончаренко, А. М. (2009). Методичні аспекти реалізації Базової програми роз- витку дитини дошкільного віку "Я у Світі". Київ : Світич.

Нижник, О. М. (2004). Допомога дітям з особливими потребами: Психолог. Бібліотека. Київ : Главник.

Dubkovetska, I., Budnyk, O., Sydoriv, S. (2016). Implementing Inclusive Education in Ukraine: Problems and Perspectives. Journal of Vasyl Stefanyk Precarpathian National University. Scientific Edition: Series of Social and Human Sciences, 3 (2-3), 99-105. Doi 10.15330/jpnu.3.2-3.99-105.

\section{REFERENCES}

Bohush, A. M. (2012). Bazovyi komponent doshkilnoi osvity. Kyiv.

Budnyk, O. B. (2015). Inkliuzyvna osvita. Ivano-Frankivsk : Vydavets Kushnir H. M.

Bohush, A. M., Varianytsia, L. O., Havrysh, N. V., Kurinna, S. M., Pechenko, I. P. (2006). Dity i sotsium: osoblyvosti sotsializatsii ditei doshkilnoho ta molodshoho shkilnoho viku. Luhansk: Alma-mater.

Patrykieieva, O. O., et al. (2011). Indeks inkliuzii: zahalnoosvitnii navchalnyi zaklad. Kyiv : Pleiady.

Kasianenko, O. M. (2018). Formuvannia hotovnosti maibutnikh vykhovateliv do roboty $\mathrm{z}$ ditmy doshkilnoho viku v umovakh inkliuzii. (Dys. kand. ped. nauk). Ternopil.

Kuzava, I., Yarmoliuk, M. (2016). Formuvannia profesiinoi hotovnosti maibutnikh vykhovateliv do vprovadzhennia inkliuzyvnoi osvity. Naukovyi visnyk Skhidnoievropeiskoho natsionalnoho universytetu imeni Lesi Ukrainky. Pedahohichni nauky, 2 (2), 75-81. Retrieved from http://nbuv.gov.ua/ UJRN/Nvvnup_2016_2\%282\%29_14

Kononko, O. L., Plokhii, Z. P., Honcharenko, A. M. (2009). Metodychni aspekty realizatsii Bazovoi prohramy rozvytku dytyny doshkilnoho viku "Ia u Sviti". Kyiv : Svitych.

Nyzhnyk, O. M. (2004). Dopomoha ditiam z osoblyvymy potrebamy: Psykholoh. Biblioteka. Kyiv: Hlavnyk.

Dubkovetska, I., Budnyk, O., Sydoriv, S. (2016). Implementing Inclusive Education in Ukraine: Problems and Perspectives. Journal of Vasyl Stefanyk Precarpathian National University. Scientific Edition: Series of Social and Human Sciences, 3 (2-3), 99-105. Doi 10.15330/jpnu.3.2-3.99-105.

Стаття надійшла 27.03.2020 p. 